\title{
Epidemiologi Diskriptif Penyakit Avian Flu di Lima Provinsi di Indonesia, 2005-2006
}

\author{
Ajeng Tias Endarti* Ratna Djuwita**
}

\begin{abstract}
Jumlah kasus flu burung pada manusia meningkat sangat pesat. Studi ini bertujuan untuk mengetahui gambaran epidemiologi penyakit flu burung (Avian Influenza / Al) pada kejadian luar biasa di 5 provinsi Indonesia in 2005-2006. Studi ini mengunakan sumber data sekunder data surveilens, sub direktorat Surveilens, Depkes $\mathrm{RI}$, pada periode Juli 2005-2006. Dari 28 kasus konfirmasi ditemukan banyak pada pria (57.1\%). Sekitar $89.3 \%$ kasus memperlihatkan gejala demam tinggi $\left(\geq 38^{\circ} \mathrm{C}\right)$, batuk dan masalah pernapasan dan sekitar $80 \%$ diantaranya meninggal dunia. Gejala tersebut mengindikasikan kerusakan jaringan paru-paru pada tubuh penderita. Berdasarkan laporan hasil pemeriksaan laboratorium, terlihat bahwa $60.7 \%$ penderita mengalami penurunan kadar leukosit (leucopenia) dan $46.4 \%$ penurunan kadar trombosit (thrombocytopenia). Laju fatalitas kasus yang telah mendapat pengobatan Tamiflu mencapai $66.7 \%$. Sekitar $53.6 \%$ mempunyai riwayat kontak dengan ayam dan bebek. Banyak kasus terjadi pada kelompok dewasa (> 18 years) dengan frekuensi $57.1 \%$. Sebaliknya, laju respon untuk kasus, terlihat sekitar 64 , $3 \%$ mengalami pengobatan yg terlambat. Rata-rata semua kasus konfirmasi di Indonesia pada July 2005 - February 2006 adalah 3.5 kasus /bulan. Kasus-kasus tersebut terjadi dalam wilayah yang mengalami KLB pada binatang ternak. Sampai 28 Februari, 2006, KLB telah ditemukan di lima provinsi yang meliputi: Lampung (10.72\%), DKI Jakarta (32.14), Jawa Barat (39.29\%), Banten (14.28\%) and Jawa Tengah (3.57\%). Dapat disimpulkan bahwa kasus lebih sering ditemukan pada pria dewasa dan pada orang yang lebih terpapar dengan faktor risiko. Kasus-kasus tersebut menampilkan gejala demam tinggi, batuk, masalah-masalah pernapasan leukopenia and trombositopenia. Selain itu, angka dan keefektifan ditemukan rendah. Kasus-kasus tersebut terjadi terutama pada musim hujan dan pada wilayah yang sebelumnya mengalami KLB pada binatang seperti ayam dan bebek.
\end{abstract}

Kata kunci: Avian flu, epidemiologi diskriptif , kejadian luar biasa, Indonesia

\begin{abstract}
The number of Human Avian Influenza in Indonesia increasing tremendously. The research is intended to identify the epidemiological description of Avian Influenza's (Al) outbreaks within five provinces in Indonesia in 2005-2006. The research conducted descriptively using Al surveillance data from July 2005 up until February 2006. The data gained from the Surveillance sub-directorate Ministry of Health of Indonesia. From 28 confirmed Al cases, many occurred to male (57.14\%) since Approximately $89.29 \%$ of the cases showed symptom of high fever $\left(\geq 38^{\circ} \mathrm{C}\right)$, cough and respiratory problems and $80 \%$ of such cases resulted to deceased for the victim. The symptoms indicated that severe destruction of tissue (pneumonia) occurred in the victim body. Based on laboratory's report, it shows $60.71 \%$ of leucopenia and $46.43 \%$ of thrombocytopenia cases. The death rate for the cases that have Tamiflu treatment reached $66.67 \% .53 .57 \%$ of the case reveals the victims' high interactions with chicken and duck as the risk factor (avian). Many cases occurred to adult (> 18 years) with a hit rate of $57.14 \%$. On the other hand, the response rate for the cases shows that 64.29 show late treatment of the cases. The average of confirmed Al cases in Indonesia from July 2005 to February 2006 is 3.5 cases/months. The cases occurred within the area that has Al outbreak to the animal. Up until February 28,2006 , the Al outbreaks have been found within five provinces, they are: Lampung (10.72\%), DKI Jakarta (32.14), West Java (39.29\%), Banten (14.28\%) and Central Java (3.57\%). It can be concluded that the cases inflicted more to adult male and to those people who interact more with the risk factor. The cases reveal symptoms such as high fever, cough, respiratory problems, leucopenia and thrombocytopenia. Furthermore the cases response rates and Tamiflu effectively were low. The cases occurred mainly in rainy seasons and to the areas those priories have Al outbreaks to the animals such as chickens or ducks.
\end{abstract}

Key words: Avian flu, descriptive epidemiology , outbreak, Indonesia

${ }^{*}$ Mahasiswa Epidemiologi Fakultas Kesehatan Masyarakat Universitas Indonesia, ${ }^{* *}$ Staf Pengajar Departemen Epidemiologi Fakultas Kesehatan Masyarakat Universitas Indonesia 
Virus yang dapat menyerang manusia dan hewan tersebut adalah virus influenza tipe A, dengan subtipe H5N1, yang dikenal sebagai virus Avian Influenza. Reservoir alami virus tersebut adalah unggas air yang berimigrasi dan ayam, terutama ayam ras. ${ }^{1}$ Manusia yang terinfeksi Avian Influenza menunjukkan gejala seperti terkena flu biasa. Dalam perkembangannya kondisi tubuh menurun drastis, jika tidak segera mendapat pertolongan, korban dapat meninggal karena berbagai komplikasi. Komplikasi yang mengancam jiwa adalah gagal napas dan gangguan fungsi tubuh lainnya. ${ }^{2}$

Di dunia, Avian Influenza masih menjadi masalah kesehatan masyarakat yang serius, karena sudah menyerang manusia dan menelan banyak korban. Avian Influenza yang pertama kali menyerang manusia dilaporkan di Hongkong pada tahun 1997. Selama Kejadian Luar Biasa (KLB) tersebut dilaporkan 18 orang dirawat di rumah sakit dan delapan orang meninggal dunia. ${ }^{3}$ Berdasarkan laporan yang masuk ke Badan Kesehatan Dunia (WHO), sejak tahun 2003 hingga tanggal 27 Februari 2006, tercatat jumlah kasus Avian Influenza yang confirmed laboratorium mencapai 173 kasus dan 93 kasus $(53,8 \%)$ di antaranya meninggal dunia. Negara dengan jumlah kasus Avian Influenza terbanyak adalah Vietnam (93 kasus) sekitar 53,8\% dari total kasus di seluruh dunia dengan kematian 45,16\%.4

Indonesia menempati urutan ke dua kasus terbanyak di seluruh dunia dengan 28 kasus $(15,6 \%)$ dan kematian $74,1 \%$, setelah Thailand dengan 22 kasus $(12,72 \%)$ dan kematian $(63,6 \%) .{ }^{4}$ Sampai dengan akhir Februari 2006, penyebaran kasus Avian Influenza pada manusia baru terjadi di lima propinsi di Indonesia, yakni DKI Jakarta, Jawa Barat, Banten, Jawa Tengah dan Lampung. Penelitian ini bertujuan mengetahui gambaran epidemiologi distriptif kasus Avian Influenza di lima propinsi di Indonesia pada tahun 2005-2006.

\section{Metodologi}

Penelitian dengan sumber data sekunder surveilens flu burung Sub Direktorat Surveilens, Depkes RI, Juli 2005 Februari 2006 ini menggunakan disain studi epidemiologi kasus seri. Metode analisis yang digunakan adalah analisis diskriptif yang mendistribusikan kasus berdasarkan berbagai variabel guna melihat berbagai kecenderungan tertentu. Variabel yang diamati adalah variabel orang (jenis kelamin, gejala klinis), hasil pemeriksaan laboratorium (leukosit dan trombosit), pengobatan yang diberikan (tamiflu), kontak dengan faktor resiko (unggas, unggas mati dan pupuk kandang), umur dan response rate. Selain itu juga diambil data mengenai variabel berdasarkan waktu dan tempat.

\section{Hasil}

\section{Jenis Kasus Avian Influenza}

Kasus Avian Influenza dibedakan atas tiga jenis yang meliputi kasus confirmed, probable, dan suspect. Kasus con- firmed adalah kasus suspek yang telah mendapat kepastian hasil pemeriksaan laboratorium. Kasus suspek adalah kasus yang dengan unggas yang mati karena virus H5N1, hasil laboratorium positif untuk virus H5N1 tetapi kasus tidak menunjukkan gejala-gejala klinis yang diduga penyakit Avian Influenza. Semua kasus Avian Influenza yang dilaporkan kepada Subdit Surveilens Dirjen PPM\&PL berjumlah 169 kasus. Kasus terbanyak adalah kasus suspect dan yang paling sedikit adalah kasus terpapar (Lihat tabel 1).

Tabel 1. Jenis Kasus Avian Influenza

\begin{tabular}{llll}
\hline Kriteria Kasus & Kasus & $\%$ & CFR \\
\hline Confirmed & 28 & 16.6 & 71.4 \\
Probable & 10 & 5.9 & 40.0 \\
Suspect & 130 & 76.9 & 21.5 \\
Terpapar & 1 & 0.6 & 0.0 \\
\hline Total & 169 & 100.0 & 30.8 \\
\hline
\end{tabular}

Kasus yang diamati selanjutnya adalah kasus confirmed Avian Influenza, yaitu kasus tersebut sudah dipastikan terjangkit virus H5N1 berdasarkan hasil pemeriksaan laboratorium.

\section{Gejala Klinis}

Gejala-gejala klinis yang diamati dari pasien kasus confirmed Avian Influenza adalah panas $\geq 38^{\circ} \mathrm{C}$, sakit tenggorokan, pilek, batuk, sesak dan diare. Dari keenam gejala tersebut, panas $\geq 38^{\circ} \mathrm{C}$ dan batuk terlihat dialami oleh semua kasus. Sedangkan gejala yang ditemukan paling sedikit adalah diare. Berdasarkan gejala-gejala klinis tersebut di atas, kasus-kasus yang dilaporkan dikelompokkan menjadi kasus yang mengalami panas $\geq 38^{\circ} \mathrm{C}$, batuk dan sesak, serta kasus yang tidak mengalami ketiga gejala tersebut. Terlihat bahwa kasus yang mengalami panas, batuk dan sesak memiliki tingkat kematian yang sangat tinggi yang mencapai $80.00 \%$. Sedangkan kasus-kasus yang tidak mengalami gejala tersebut tidak ada yang meninggal dunia. Sebagian besar kasus dengan leukopenia dan trombositopenia $(92.31 \%)$ meninggal dunia (Lihat Tabel 2).

\section{Distribusi Berdasarkan Variable Orang}

Gambaran kejadian confirmed Avian Influenza berdasarkan variabel orang (jenis kelamin dan umur) mem-

Tabel 2. Tabel Gejala Klinis Kasus Confirmed Avian Influenza

\begin{tabular}{llll}
\hline Gejala yang dirasakan & Kasus & $\%$ & CFR \\
\hline Panas $\geq 38^{\circ} \mathrm{C}$ & 28 & 100.00 & 71.43 \\
Batuk & 28 & 100.00 & 71.43 \\
Sesak & 25 & 89.29 & 80.00 \\
Leukopenia & 17 & 60.71 & 64.71 \\
Trombositopenia & 13 & 46.43 & 92.31 \\
Sakit Tenggorokan & 6 & 21.43 & 83.33 \\
Pilek & 5 & 17.86 & 80.00 \\
Diare & 2 & 7.14 & 100.00 \\
\hline
\end{tabular}


perlihatkan bahwa kasus lebih banyak terjadi pada pria daripada pada wanita. Tetapi tingkat kematian wanita lebih tinggi daripada pria. Dilihat dari variabel umur, kasus paling banyak terjadi pada usia dewasa (> 18 tahun) dan paling sedikit terjadi pada balita. Sedangkan untuk tingkat kematian tertinggi terjadi pada usia balita dan terendah terjadi pada anak usia sekolah. (Lihat Tabel 3)

Tabel 3. Distribusi Berdasarkan Jenis Kelamin dan Umur

\begin{tabular}{llll}
\hline Variabel & Kasus & $\%$ & CFR \\
\hline Jenis Kelamin & & & \\
Pria & 16 & 57.14 & 56.25 \\
Wanita & 12 & 42.86 & 91.67 \\
Umur & 1 & & \\
Balita (<5 tahun) & 10 & 3.57 & 100.00 \\
Anak Usia Sekolah (5-18 tahun) & 16 & 35.71 & 40.00 \\
Dewasa (> 18 tahun) & 1 & 57.14 & 87.50 \\
Tidak diketahui & & 3.57 & 100.00 \\
\hline Total & 28 & 100.00 & 71.43 \\
\hline
\end{tabular}

Sampai akhir masa pengamatan, kasus confirmed Avian Influenza dilaporkan hanya terjadi di lima propinsi, yaitu Lampung, DKI Jakarta, Jawa Barat, Jawa Tengah dan Banten. Kasus tertinggi ditemukan di Jawa Barat dan yang terendah di Jawa Tengah.

Kasus confirmed Avian Influenza pertama kali terjadi di Indonesia pada bulan Juli 2005 dan selama masa pengamatan sampai bulan Februari 2006, dilaporkan terjadi 28 kasus confirmed Avian Influenza, mencapai puncaknya pada bulan September 2005 (6 kasus). Pada bulan Agustus 2005 tidak ada kasus yang dilaporkan. Selama masa pengamatan dilaporkan rata-rata kejadian confirmed Avian Influenza di Indonesia mencapai 3,5 kasus/bulan ( Lihat Tabel 4)

Tabel 4. Distribusí Berdasarkan Variabel Tempat dan Waktu

\begin{tabular}{llll}
\hline Variabel & Kasus & $\%$ & CFR \\
\hline Tempat & & & \\
Lampung & 3 & 10.71 & 0.00 \\
DKI Jakarta & 9 & 32.14 & 88.89 \\
Jawa Barat & 11 & 39.29 & 81.82 \\
Jawa Tengah & 1 & 3.57 & 0.00 \\
Banten & 4 & 14.29 & 75.00 \\
& & & \\
Waktu & & & \\
Juli 2005 & 1 & 3.57 & 100.00 \\
Agustus & 0 & 0.00 & 0.00 \\
September & 6 & 21.43 & 50.00 \\
Oktober & 3 & 10.71 & 33.33 \\
November & 5 & 17.86 & 80.00 \\
Desember & 3 & 10.71 & 66.67 \\
Januari 2006 & 5 & 17.86 & 80.00 \\
Februari & 5 & 17.86 & 100.00 \\
\hline
\end{tabular}

\section{Faktor Risiko \& Prognosis}

Pada kasus confirmed Avian Influenza yang dilaporkan, jenis kontak dengan faktor risiko yang diamati yang meliputi kontak dengan unggas, unggas mati, dan pupuk kandang. Kontak yang paling banyak dialami adalah dengan unggas mati. Sedangkan kontak yang paling sedikit dilakukan adalah dengan pupuk kandang. Selanjutnya, kontak tersebut dikategorikan dalam banyak kontak dan sedikit kontak. Dinyatakan sebagai banyak kontak jika kasus mempunyai riwayat kontak dengan minimal dua faktor risiko dan sedikit kontak jika riwayat kontak hanya dengan satu faktor risiko. Kasus yang melakukan banyak kontak terlihat lebih besar dari pada yang melakukan sedikit kontak. Walaupun demikian tingkat kematian pada kasus yang melakukan sedikit kontak lebih banyak daripada tingkat kematian pada kasus yang melakukan banyak kontak.

Kasus yang mendapatkan Tamiflu hanya 64,3\%, tetapi dengan tingkat kematian yang cukup tinggi $(66.7 \%)$. Meskipun demikian, angka kematian itu relatif lebih rendah daripada kelompok kasus yang tidak mendapat Tamiflu $(83.33 \%)$. Sebagian besar kasus mendapatkan Tamiflu setelah lebih dari 2 hari onset. Tingkat kematian pada kasus ini pun lebih tinggi jika dibandingkan dengan kasus yang mendapat Tamiflu kurang dua hari setelah onset.

Kecepatan respon atas tiga kategori yang meliputi respon cepat, sedang dan lambat. Kecepatan respon yang ditemukan paling banyak adalah yang lambat dengan tingkat kematian paling tinggi. Sedangkan yang paling sedikit adalah response yang cepat dengan tingkat kematian yang paling kecil (Lihat Tabel 5).

Tabel 5. Distribusi Berdasarkan Faktor Risiko \& Prognosis

\begin{tabular}{llll}
\hline Faktor Risiko / prognosis & Kasus & $\%$ & CFR \\
\hline Jenis Kontak & & & \\
Langsung & 5 & 17.86 & 40.00 \\
Tidak Langsung & 16 & 57.14 & 75.00 \\
Unggas Mati & 17 & 60.71 & 58.82 \\
Pupuk Kandang & 2 & 7.14 & 100.00 \\
& & & \\
Jumlah Kontak & 13 & 46.4 & 84.6 \\
Sedikit & 15 & 53.6 & 60.0 \\
Banyak & & & \\
& 2 & 7,2 & 0,0 \\
Obat Tamiflu & 20 & 71,4 & 80.0 \\
Ya $\leq 2$ hari & 6 & 21.4 & 83.3 \\
Tidak & & & \\
Tidak Diketahui & & & \\
Response Rate & 3 & 10.7 & 33.3 \\
Cepat (<3 hari) & 5 & 17.9 & 80.0 \\
Sedang (3-5 hari) & 18 & 64.3 & 77.8 \\
Lambat (> 5 hari) & 2 & 50.0 \\
Tidak Diketahui & & & \\
\hline
\end{tabular}

\section{Pembahasan}

Penelitian ini menemukan bahwa kasus confirmed Avian Influenza terjadi lebih besar pada pria dari pada wanita. Hal ini mungkin disebabkan oleh pria yang lebih banyak mengalami kontak dengan faktor risiko $(56,2 \%)$ daripada wanita $(50 \%)$. Berdasarkan tingkat kematian, pria $(56,2 \%)$ mengalami tingkat kematian relatif lebih kecil daripada 
wanita mencapai $(91,67 \%)$. Kematian pada wanita yang tinggi ini kemungkinan disebabkan oleh proporsi wanita yang berhubungan dengan variabel-variabel yang mempengaruhi tingkat kematian pada kasus ini cukup besar. Variabel-variabel tersebut adalah response rate pada wanita (83.33) relatif lebih lambat daripada pria $(81.25 \%)$. Berdasarkan hasil pemeriksaan laboratorium, trombositopeni pada wanita $(58.3 \%)$ lebih besar daripada pria $(37.50 \%)$. Hal yang sama ditemukan pada gejala panas dan sesak napas pada perempuan $(91.7 \%)$, lebih besar daripada pria $(87.5 \%)$.

\section{Gejala Klinis}

Dari enam gejala yang diamati pada kasus confirmed Avian Inflluenza tersebut, ada tiga gejala yang dialami oleh hampir semua kasus. Gejala-gejala tersebut adalah panas $\geq$ $38^{\circ} \mathrm{C}$ dan batuk yang dialami oleh semua kasus, serta sesak yang dialami oleh $89.29 \%$ kasus. Berdasarkan data tersebut, kasus dibedakan menjadi kasus dengan panas $238^{\circ} \mathrm{C}$, batuk dan sesak serta kasus yang tidak mengalami ketiga gejala tersebut. Semua kasus yang tanpa tiga gejala tersebut $(100 \%)$ dapat bertahan hidup, tetapi kasus yang mengalami ketiga gejala tersebut hanya $20 \%$ yang dapat bertahan hidup. Angka fatalitas kasus dengan ketiga gejala tersebut tinggi, karena terjadi pneumonia akibat kejadian cytokine store perubahan asam glutamat menjadi asam aspartat. Hal tersebut menyebabkan patogenitas virus H5N1 meningkat. Gejala-gejala tersebut timbul akibat sitokinin sebagai dampak peningkatan tumor necrosis factor alpha (TNF $\alpha)$ akibat infeksi virus H5N1.5 Infeksi virus H5N1 meningkatkan sitokinin lebih besar daripada infeksi virus influenza biasa. ${ }^{6}$ Pada infeksi ulang virus lain, tubuh sudah membentuk kekebalan, tapi pada virus H5N1 yang belum dikenal imunitas tersebut belum terbentuk.

\section{Pemeriksaan Laboratorium}

Pemeriksaan laboratorium kasus confirmed Avian Influenza biasanya memperlihatkan tanda-tanda leukopenia, trombositopenia dan peningkatan aminotransferase. Berdasarkan penelitian yang dilakukan di Thailand, penurunan leukosit dan trombosit ini berhubungan dengan peningkatan angka kematian pada kasus Avian Influenza. Hasil ini sesuai dengan temuan penelitian ini, kasus dengan leukopenia dan trombositopenia memperlihatkan angka kematian yang lebih $(92.31 \%)$ daripada yang tidak mengalami kedua hal tersebut $(64.71 \%)$.

Angka kematian pada kasus dengan leukopenia dan trombositopenia yang tinggi mengindikasikan gangguan pembentukan darah atau adanya kesalahan dalam merespon infeksi. ${ }^{5}$ Leukopenia ditentukan berdasarkan jumlah leukosit dalam darah yang kurang dari $5000 / \mathrm{mm}^{3}$. Wikipedia menyebutkan bahwa virus influen. Infeksi virus H5N1 yang sebelumnya tidak ada, tidak merangsang pembentukan antibodi. Akibatnya, tubuh tidak dapat mengha- lau virus yang masuk. Jumlah trombosit darah yang rendah (trombositopenia) terjadi akibat kesalahan antibodi yang terjadi di dalam limfa menghancurkan trombosit sendiri yang dapat mengakibatkan perdarahan.

Trombositopenia berhubungan dengan kerja antibodi dalam tubuh. Pada kejadian trombositopenia, antibodi yang seharusnya melawan virus H5N1, malah menghancurkan trombosit. Penyimpangan kerja antibodi tersebut berpengaruh terhadap sistem kekebalan tubuh individu, mengingat antibodi adalah zat terlarut yang merupakan komponen sistem kekebalan tubuh. Komponen yang lain adalah sel darah putih (makrofag, neutrofil dan limfosit) dan zat terlarut lainnya (protein komplemen dan sitokinesis). Daya tahan tubuh wanita dipengaruhi juga oleh leukopenia. Kasus confirmed Avian Influenza tidak hanya mengalami trombositopenia, tetapi juga mengalami leukopenia ytang menyebabkan tubuh sulit untuk mengenali, mencerna dan menghancurkan virus Avian Influenza H5N1. ${ }^{7}$

\section{Umur}

Penelitian ini menemukan bahwa kasus terbanyak pada usia dewasa $(57,1 \%)$ dan yang paling sedikit pada usia balita $(3,57 \%)$. Hasil tersebut sesuai dengan temuan CDC bahwa kasus Avian Influenza lebih banyak terjadi pada anak-anak dan dewasa muda, akibat risiko terpapar yang lebih tingi. Proporsi kasus yang sebelumnya telah terpapar dengan beberapa faktor risiko adalah $56,2 \%$. Kasus pada balita terjadi akibat sistem kekebalan yang belum kuat. ${ }^{2}$ Keterpajanan dengan virus H5N1 yang mungkin berasal langsung dari unggas, yang menderita Avian Influenza $(100 \%)$. Hal tersebut memperlihatkan bahwa balita merupakan kelompok risiko tinggi yang perlu dijaga agar tidak kontak dengan burung dan unggas. Laju Fertalitas kasus pada balita mencapai $100 \%$, diikuti oleh dewasa $(87,5 \%)$ dan anak usia sekolah (40\%). Hasil ini sesuai dengan laporan penelitian sebelumnya bahwa tingkat kematian infeksi H5N1 tertinggi terjadi pada balita (89\%). Perbedaan angka kematian tersebut disebabkan oleh perbedaan response rate yang dilakukan. Kematian Balita tinggi karena penanganan kasus yang lambat (>2 hari).

\section{Waktu}

Di Indonesia kasus Avian Influenza pada manusia yang pertama kali dan berakhir dengan kematian terjadi pada bulan Juli 2005. Kasus tersebut mengagetkan karena dialami oleh orang yang tidak bekerja di peternakan dan yang rumahnya jauh dari lokasi peternakan. Memasuki musim hujan, pada bulan September 2005, terjadi peningkatan kasus 6 kali lipat dari kasus pada bulan Juli 2005. Setelah itu, sampai bulan Februari 2006 dilaporkan selalu ada kasus baru dengan jumlah yang berfluktuasi. Cuaca ketika terjadi endemis Avian Influenza pada periode September 2005Februari 2006, sama dengan cuaca ketika terjadi KLB pada hewan tahun 2004, yaitu musim hujan. ${ }^{8}$ 
Pada musim dingin, burung-burung liar bermigrasi ke arah selatan melintasi Indonesia yang terletak pada $6^{\circ} \mathrm{LU}-$ $11^{\circ}$ LS ("Profil Indonesia", 2005). Migrasi burung liar yang merupakan resevoir virus $\mathrm{H} 5 \mathrm{~N} 1$ tersebut, ${ }^{9}$ dimulai pada bulan Juli dan semakin lama semakin banyak. ${ }^{10}$ Migrasi tersebut akan menularkan virus pada hewan-hewan domestik yang ada di jalur perjalanan mereka. Para ilmuwan meyakini bahwa burung-burung liar/ burung air yang bermigrasi membawa virus H5N1 dalam bentuk HPAI. ${ }^{6}$ Hal ini terbukti dengan kejadian luar biasa (KLB) Avian Influenza pada hewan di Asia Tenggara yang terjadi pada musim dingin 2003-2004. Saat itu, kepadatan burung-burung liar di Asia Tenggara berada pada puncaknya. Semakin banyak hewan peliharaan yang terinfeksi maka risiko penularan pada manusia semakin besar. ${ }^{10}$

Suhu lingkungan yang relatif lebih rendah itu akan membuat virus bertahan lebih lama, karena dia mampu bertahan hidup di air pada suhu $22^{\circ} \mathrm{C}$ sekitar empat hari. ${ }^{10}$ Sifat virus ini secara teoritis dapat menular pada manusia melalui hidung. Peningkatan kasus pada musim dingin juga disebabkan oleh kebiasaan tinggal di dalam rumah dan kebiasaan membawa ternak mereka ke dalam rumah. Hal tersebut menyebabkan kontak yang lebih sering, sehingga risiko penularan antar hewan ataupun hewan ke manusia menjadi lebih besar. ${ }^{11}$

\section{Tempat}

Penyakit Avian Influenza adalah penyakit zoonosis, sehingga peningkatan kasus pada hewan akan meningkatkan risiko penularan pada manusia akan semakin besar. Di Indonesia, sampai dengan bulan Februari 2006, kasus confirmed Avian Influenza telah terjadi di Provinsi Lampung, DKI Jakarta, Jawa Barat, Banten dan Jawa Tengah. Kelima provinsi tersebut sebelumnya telah mengalami kejadian kasus Avian Influenza pada unggas ataupun hewan lainnya.

Jalur Pantai utara (Pantura) khususnya Kabupaten Indramayu dengan wilayah udara yang setiap musim menjadi jalur lalu lintas jutaan burung, termasuk daerah yang terjangkit virus H5N1. Dalam perjalanan migrasi, burung dari Australia atau Eropa yang menempuh ribuan kilometer menjadikan kepulauan Rakit sebagai tempat peristirahatan atau transit. Pulau Rakit Utara, Gosong dan Rakit Selatan atau Pulau Biawak menjadi tempat persinggahan jutaan ekor burung selama, 2 - 2,5 bulan untuk bereproduksi, kawin, dan bahkan sampai menetaskan telurnya. ${ }^{12}$

Propinsi Lampung adalah propinsi kedua yang paling sedikit memiliki kasus confirmed Avian Influenza pada manusia setelah propinsi Jawa Tengah. Semua kasus, sebanyak tiga orang atau sekitar $10,71 \%$ dari total kasus di Indonesia, terjadi di Kabupaten Tenggamus. Adanya kasus confirmed Avian Influenza di daerah tersebut karena di Kabupaten Tenggamus, begitu juga dengan Tulang Bawang, Bandar Lampung dan Lampung Barat, mengalami kematian unggas sebanyak 4.355 ekor dan berdasarkan hasil penye- lidikan dan surveilens penyakit didapatkan hasil 46 unggas positif terinfeksi Avian Influenza. ${ }^{13}$

Jumlah kasus confirmed Avian Influenza di DKI Jakarta sembilan kasus yang menjadikan Jakarta sebagai provinsi dengan kasus confirmed Avian Influenza terbanyak kedua setelah provinsi Jawa Barat. Kasus tersebut menyebar di empat kotamadya di DKI Jakarta, yaitu Jakarta Barat, Jakarta Selatan, Jakarta Timur dan Jakarta Pusat. Hal tersebut disebabkan oleh DKI Jakarta telah terjadi kasus Avian Influenza pada unggas. Populasi unggas DKI Jakarta adalah 36.526 ekor, yang terdiri dari 29.819 ekor ayam, itik dan enthok serta 6.717 ekor burung dan unggas. Kasus Avian Influenza positif adalah 21 kasus Jakarta Pusat (5), Jakarta Barat (1) dan Jakarta Timur (15). ${ }^{14}$

Jawa Barat memiliki kasus confirmed Avian Influenza paling banyak di Indonesia. Jumlah kasus pada manusia mencapai 11 (39,29\%) dan tersebar di enam kabupaten/kota. Kabupaten/kota yang terinfeksi Avian Influenza ini adalah Bandung, Bogor, Depok, Sumedang, Indramayu dan Bekasi. Angka kejadian Avian Influenza pada manusia yang tinggi tersebut sebanding dengan tingkat kejadian pada hewan. Jumlah desa yang terkena endemis Avian Influenza di Jawa Barat sampai dengan Februari 2006 mencapai 103 desa dan meningkat menjadi 168 desa pada bulan Maret 2006. Peningkatan yang tinggi tersebut diduga akibat pengawasan Dinas Peternakan yang kurang. ${ }^{15}$

Hingga Februari 2006, di provinsi Banten ditemukan empat kasus dan semuanya terjadi di Kabupaten Tangerang. Menurut Departemen Pertanian, kejadian bermula dari kasus positif Avian Influenza pada babi. Dinas Pertanian dan Peternakan Kabupaten Tangerang mengantisipasi penyebaran virus $\mathrm{H} 5 \mathrm{~N} 1$ dengan melaksanakan survey dan vaksinasi terhadap unggas yang berada pada radius $20 \mathrm{~km}$ dari lokasi tempat pertama kali kasus pada hewan ditemukan. Selain itu dilakukan juga surveilens terhadap manusia untuk mengantisipasi dan mencegah timbulnya kasus baru. ${ }^{16}$

Jawa Tengah adalah propinsi yang paling sedikit menemukan kasus confirmed Avian Influenza, (3,6\% dari total kasus). Kasus hanya ditemukan di Kabupaten Magelang. Pada tahun 2005, kasus Avian Influenza yang ditemukan mencapai 80 kasus burung puyuh. Jumlah tersebut jauh lebih kecil daripada kasus ungas pada tahun 2004, yang mencapai 8.178.493 ekor yang menempatkan propinsi Jawa Tengah sebagai propinsi dengan kasus Avian Influenza terbanyak pada hewan. ${ }^{14}$ Kejadian kasus yang paling tinggi pada hewan tersebut ternyata tidak diikuti oeleh peningkatan kasus pada manusia. Kemungkinan hal ini disebabkan oleh program vaksinasi unggas gratis yang dilakukan oleh Dinas Peternakan Jawa Tengah Sebanyak 23,2 juta dosis vaksin flu burung dibagikan secara cuma-cuma kepada peternak unggas. Selain itu juga dilakukan pemusnahan ternak dan pakan ternak yang sudah terinveksi virus flu burung. ${ }^{14}$

Selain cuaca, kejadian kasus pada hewan tersebut juga dipengaruhi oleh migrasi burung-burung liar. Virus H5N1 
dengan patogenitas yang tinggi (HPAI) dapat bertahan lama pada lingkungan dengan suhu udara yang rendah. ${ }^{17}$ Terlihat bahwa daerah yang rata-rata suhu udaranya rendah berisiko lebih besar terserang penyakit Avian Influenza. Kabupaten Bandung, Bogor dan kabupaten Magelang dengan suhu udara rata-rata-nya $23,5^{\circ}, 24^{\circ} \mathrm{C}$ dan Kabupaten Magelang yang dikelilingi pegunungan dan beriklim sejuk yang cocok untuk budidaya unggas. ${ }^{18}$

\section{Kontak Dengan Faktor Risiko}

Penelitian evolusi virus Avian Influenza $\mathrm{H} 5 \mathrm{~N} 1$ yang dilakukan WHO di Asia, menyatakan bahwa gen HA virus H5N1 yang diisolasi dari spesimen manusia berhubungan erat dengan gen HA dari virus H5N1 yang secara alami berasal dari burung. Perbedaan antara kedua gen HA tersebut terdapat pada 2-14 nukleotida (penyimpangan $<1 \%$ ). Hal ini sesuai dengan data-data epidemiologi bahwa manusia yang terinfeksi virus $\mathrm{H} 5 \mathrm{~N} 1$ berasal dari kontak langsung maupun tidak langsung dengan unggas atau produk-produk unggas. ${ }^{19}$ Bukti-bukti terakhir mengindikasikan bahwa unggas yang mati atau yang sakit adalah sumber utama penularan virus $\mathrm{H} 5 \mathrm{~N} 1$ pada manusia.

Semakin sering kontak semakin besar pula risiko untuk tertular virus Avian Influenza H5N1 Karena virus yang sifatnya airborne infection ini dapat terbang di udara di sekitar lokasi unggas. Virus dapat berasal dari kotoran, liur, wadah makanan, air minum, kandang dan semua permukaan tanah yang dicemarinnya. Penularan juga dapat terjadi melalui kontak langsung lewat tangan yang menyentuh, memegang atau bersinggungan dengan semua yang tercemar virus, termasuk saat berkontak dengan unggas atau telurnya. Tangan yang tercemar dan tidak dibasuh dan berkontak dengan lubang hidungnya, virus Avian Influenza yang mencemari tangan dapat memasuki saluran pernafasan. Kontak tidak langsung dapat terjadi melalui kontak dengan faeces unggas yang terinfeksi, yang dapat mengandung virus $\mathrm{H} 5 \mathrm{~N} 1$ dalam jumlah besar. ${ }^{20}$

\section{Response Rate}

Response rate yang merupakan kecepatan pencarian pengobatan dalam satuan hari, terhitung sejak onset timbulnya penyakit berhubungan dengan kematian. Pada penelitian ini, proporsi kasus terkecil $(10,7 \%)$ ditemukan pada response rate yang cepat $(<3 \mathrm{hr})$, diikuti dengan yang sedang (3-5 hari) dan yang lambat ( $>5$ hari) masing-masing adalah $17,8 \%$ \& $64,3 \%$. Response yang lambat tersebut mungkin terjadi akibat para penderita mengganggap penyakit tersebut sebagai influenza biasa yang akan sembuh dalam beberapa hari. Temuan tersebut sesuai dengan teori ekspektasi perilaku sehat, bahwa tindakan seseorang berhubungan dengan keinginan untuk menurunkan ketidak berdayaan, keparahan dan estimasi keuntungan biaya yang telah dikeluarkan. ${ }^{21}$

Kematian kasus dengan response rate yang sedang dan lama masing-masing ditemukan tinggi $(80 \% \& 77,8 \%)$, sedangkan pada yang cepat rendah $(33,3 \%)$. Keadaan ini membuktikan tingkat kematian Avian Influenza yang tinggi, sehingga memerlukan penanganan yang cepat. Penelitian di Thailand, menemukan periode 4-13 hari setelah onset dapat menyebabkan gangguan pernafasan akut. Di Turki, gangguan pernafasan akut yang timbul 3-5 hari setelah onset diikuti oleh disfungsi beberapa organ tubuh, leukopenia, trombositopenia serta peningkatan enzim aminotransferase. ${ }^{20}$ Gejala-gejala lainnya adalah dyspnea, sesak nafas dan tachypnea pada hari kelima (median) setelah onset dan diikuti dengan kejadian pneumonia. Setelah itu, pada median hari ke enam, timbul kegagalan bernafas yang ditandai oleh acute respiratory distress sindrome (ARDS).

\section{Pengobatan}

Obat flu burung sampai sekarang belum ditemukan, obat yang diberikan kepada pasien flu burung hanya berfungsi meredam gejala. Badan obat dan makanan Amerika Serikat merekomendasikan empat jenis obat antiviral yang meliputi amantadine dan rimantadine (M2 inhibitor) serta oseltamivir dan zanavir yang merupakan neuraminidase inhibitor. ${ }^{22}$ Neuraminidase adalah antigen enzim glikoprotein yang terdapat pada permukaan virus influenza dan berfungsi untuk membantu pengeluaran virus dari sel. ${ }^{11}$ Obat-obatan tersebut biasa diberikan untuk pasien influenza tipe A dan tipe B. ${ }^{23}$ Tetapi virus H5N1 yang diisolasi pada Kejadian Luar Biasa (KLB) tahun 1997 di Hongkong, sudah resisten terhadap amantadine dan rimantadine. Kedua obat tersebut tidak dapat digunakan untuk penyembuhan. Kini, obat yang digunakan adalah oseltamivir dan zanavir yang dapat menghambat replikasi virus dalam tubuh. ${ }^{24}$ Untuk mendapatkan efek yang maksimal, pasien harus mendapatkan pengobatan dini segera setelah onset yang pertama kali. ${ }^{23}$

Pada penelitian ini, kasus Avian Influenza yang mendapatkan terapi oseltamivir (tamiflu) adalah 28 kasus (64,3\%) kasus dan 66,7\% diantaranya mengalami kematian. Hal tersebut terjadi akibat pemberian tamiflu yang tidak dini. pemberian oseltamivir yang efektif yaitu paling lama dua hari setelah onset. Hal ini sesuai dengan hasil analisis, dimana $100 \%$ kasus yang mendapatkan tamiflu $\leq 2$ hari setelah onset dapat bertahan hidup (7,14\% dari total kasus confirmed Avian Influenza). Sedangkan yang mendapatkan tamiflu setelah $>2$ hari ataupun yang tidak mendapatkan tamiflu $(71,43 \%$ dari total kasus confirmed Avian Influenza), 80 persen meninggal dunia. Hasil tersebut menunjukkan bahwa oseltamivir hanya efektif bagi kasus yang respons rate-nya tinggi ( $\leq 2$ hari). Oseltamivir adalah neuraminidase inhibitor yang dapat mencegah produksi virus baru dari sel-sel yang terinfeksi. ${ }^{11}$ Ketika onset muncul, virus sudah berada dalam tubuh pejamu, sehingga pemberian anti virus beberapa hari setelah onset, virus yang baru sudah terlanjur dikeluarkan dan oseltamivir tidak da- 
pat melawan virus tersebut

\section{Kesimpulan}

1. Hingga tanggal 28 Februari 2006, jumlah kasus Avian Influenza di Indonesia mencapai 28 kasus adalah kasus suspect dan yang terkecil adalah kasus terpapar dan confirmed Avian Influenza.

2. Kecenderungan distribusi kasus avian inflenza sebagai berikut:

- Sebagian besar kasus perlihatkan riwayat kontak dengan banyak faktor risiko terutama unggas yang merupakan sumber utama penularan virus H5N1 pada manusia;

- Di Indonesia, Avian Influenza terjadi di daerah yang sebelumnya pernah/sedang mengalami Kejadian Luar Biasa (KLB) pada hewan dan meningkat pada musim hujan. Sampai 28 Februari 2006, kasus confirmed Avian Influenza di Indonesia hanya terjadi di lima propinsi, yaitu Lampung, DKI Jakarta, Jawa Barat, Banten dan Jawa Tengah.

3. Kasus ditemukan lebih tinggi pada pria dan kelompok umur dewasa (> 18 tahun), tapi kematian lebih tinggi pada wanita dan balita

- Kasus yang mengalami gejala panas $\geq 38^{\circ} \mathrm{C}$, batuk, sesak leukopenia dan trombositopenia lebih banyak yang meninggal dunia.

- Tingkat kematian kasus yang mendapat pengobatan tamiflu cukup besar, semakin cepat respon rate semakin kecik risiko kematian tetapi sebagian besar kasus dengan response rate yang lambat.

\section{Saran}

1. Sosialisasi tentang Avian Influenza, meliputi gejala, risiko serta penularannya. Langkah ini dilakukan dengan penyuluhan di berbagai daerah, terutama di daerah KLB.

2. Untuk menurunkan tingkat kematian, segera berikan Obat avian flu kepada mereka yang mengalami gejala-gejala Avian Influenza. Kegiatan ini dapat dilakukan oleh puskesmas terintegrasi dengan kegiatan lain, misal dengan sosialisasi penyakit DBD, polio dan lainnya.

3. Mengingat unggas merupakan faktor risiko paling utama, maka perlu meningkatkan kewaspadaan masyarakat terhadap ungas.

\section{Daftar Pustaka}

1. Rijadi, Suprijadi. Jenis dan strain virus influenza. Indo Avian Flu, 20 September 2005. Diakses 7 Februari 2006 dari www.indoavianflu.blogspot.com

2. Judarwanto, Widodo, dr., SpA. (2005). Implikasi flu burung pada manusia, diakses 7 Februari 2006 dari http://news.indosiar.com

3. Centers for disease control and prevention. Principles of Epidemiology, $2^{\text {nd }}$ Edition; An Introduction to Applied Epidemiology and Biostatistics.

4. WHO. Avian influenza frequently asked questions, (2005). Diakses 10 April 2006 dari www.who.int

5. Wikipedia, Leukopenia, (2005), diakses 20 April 2006 dari www.wikipedia.org

6. WHO, (2006). The disease in birds. 16 Januari. Diakses 17 April 2006 dari www.who.int

7. Anonimus (2005)Biologi sistem kekebalan. Medica store, diakses 26 April 2006 dari www.medicastore.com

8. Depkes RI, Waspada flu burung, diakses 12 April 2006 dari www. Depkes.go.id

9. Soeroso, Santoso. Pandemi flu burung pada manusia: siapkah kita? Kompas, 5 Februari 2005. Diakses 6 April 2006 dari www.kompas.com

10. Anonim (2005). FAO, Animal health special report, diakses 25 April 2006 dari www. Fao.org Wikipedia (2005).

11. Anonim (2005). Wikipedia, Imunitas, 2005, diakses 26 April 2006 dari www.wikipedia.org

12. Anonim (2005) Wikipedia, Avian influenza. diakses 23 April 2006 dari www.wikipedia.org

13. Dinas Kesehatan dan Peternakan Hewan. Flu burung di Provinsi Lampung (Laboran sd 24 Februari 2006), diakses 12 April 2006 dari www.dinakkeswan-lampung.go.id

14. Anomin (2006). Tempo Interaktif. Tujuh kelurahan positif terjangkit flu burung. Tempo, 25 Februari. Diakses 26 April 2006 dari www.tempointeraktif.com

15. Santoso, Mardi, Herman Salim, \& Hasanudin Alim. (2005). Avian influenza (flu burung). Cermin Dunia Kedokteran No.148, 2005.

16. Anonim (2005). Flu Burung $20 \mathrm{Km}$ dipantau. Suara Pembaharuan, 19 Agustus. Diakses 26 April dari www.suarapembaharuan.com

17. Anonim (2006) The desease in birds. WHO, 16 Janwari, Diakses 17 April 2006 dari www.who.int

18. Anonim, (2004). Penugasan lembah tidar. Poultry Indonesia. 14 Juli. Diakses 12 April 2004 dari www.politriindonesia.com

19. CDC. Avian flu : the virus \& its spread. 2005. Diakses 6 April 2006 dari www.cdc.gov

20. WHO, The role of migratory birds. WHO, 16 Januari. Diakses 17 April 2006 dari www.who.int

21. Smet and Bart. Psikolofi kesehatan. Jakarta: PT. Gramedia,Widiasarana Indonesia; 1994.

22. Anonim. Avian influernza A (H5N1) infection in human, England Journal of Medicine, 353, (13), 29 September, 2005.

23. Brooks , Geo F, Janet. S, Butel and Stiphe A. Medical microbiology $23^{\text {th }}$ edition. Mc Grew Hill, 2004.

24. Anomim (2004). Factfile on bird flu. The Anatolian Times, 5 Januari diakses 30 Maret 2006 dari www.anatoliantime.com, 2006. 